\title{
IMPACT OF ONLINE EDUCATION ON STUDENT'S SATISFACTION AND SELF- CONFIDENCE ON LEARNING DURING COVID -19 IN PAKISTAN
}

\author{
Sahira Zaman \\ Assistant Professor, \\ Department of Gender Studies, University of the Punjab, \\ Punjab, Pakistan \\ Email: sahira_zb@hotmail.com

\section{Heeba Nashmena} \\ Ph.D. Scholar, \\ Department of Gender Studies, University of the Punjab, \\ Punjab, Pakistan \\ Email: heebanasmena@yahoo.com
}

\begin{abstract}
Educational institutions were closed in Pakistan due to the COVID-19 pandemic and started online classes to continue the education system. A web-based survey was conducted to investigate students' level of satisfaction in learning and self-confidence over proficiency in lessons learned during online classes. A fast, reliable internet facility took as a mediator between the study variables. The sample consisted of 160 university students from both rural and urban backgrounds of Punjab. Two scales; an adapted version of Student Satisfaction and Self-Confidence in Learning and an online education scale used in the study. Results showed a significant negative relationship between online education and student satisfaction, self-confidence over the material learned. However, the fast and reliable internet connection significantly mediates the levels of satisfaction and self-confidence upon learning. The study found that university students are only satisfied and confident with their material learned if the technology supports this education system.
\end{abstract}

\section{KEYWORDS}

Online Learning, Educational Satisfaction, Proficiency, COVID-19

\section{INTRODUCTION}

Coronavirus is an infectious disease commonly named COVID-19. Coronavirus has 
badly affected many sectors globally in which education and economy sectors are also included. According to the reports of UNESCO, by the end of April 2020, in 186 countries, academic -institutions were closed nationwide. $73.8 \%$ of enrolled students were affected because of the closure of academic institutions due to the coronavirus (UNESCO, 2020; Muthuprasad, Aiswarya, Aditya \& Jha 2021). Implementing lockdown and maintaining social distancing were the only solutions to slow down the spread of Coronavirus among people. The closure of academic institutions has affected many learners. Coronavirus spreads worldwide; that is why this pandemic forced academic institutions to remain closed for few months to slow down the process of the virus among people.

The COVID-19 makes the world realizes that preplanning and good planning on time is a good option for academic institutions (Rieley, 2020; Dhawan, 2020). Everyone needs to understand that in this coronavirus situation, humanity and unity both are important and necessary factors. There was an urgent need to protect all people from this virus: students, academic staff, community, societies, and the nation (Dhawan, 2020).

Online learning has many meanings, but online learning means online classes through different applications for this study. It means the real-time interaction between teachers and learners (Rapanta, Botturi, Goodyear, Guàrdia \& Koole, 2020). Other aspects of online learning are convenience, affordability, flexibility in schedules, and different learning pedagogy. Online learning is considered more accessible and approachable to rural and remote areas. Online education is beneficial as a significantly cheaper learning model than a physical learning system because students can save their time, accommodation, institution-based learning, and transportation money by taking online classes. Flexibility is also a factor of online learning because students can easily set a schedule for other courses. Students can learn anytime and anywhere through online education. The government also considered the importance of online learning in this dynamic world (Dhawan, 2020).

There are many applications available for online education, but sometimes they create many difficulties. These problems range from installation, login, audio, video, and downloading issues. The findings of a study by Jesse (2015) found that $99.8 \%$ means the majority of the students have mobile phones. They use it for different purposes, including messaging, visiting social media applications, and other applications. Rapid technology integration into the education system resulted in students' high degree of acceptance and receptiveness towards it" (Ali, 2020). 
Students also face many issues during online classes, and sometimes students find online teaching boring and unengaging compared to physical classes. There are also other issues that students are facing; for example, personal attention is one of them because students want to interact with others to discuss an issue or a topic. There is also an issue of practice because sometimes online content is based on theory and lecture-based, not practice (Song, Singleton, Hill, \& Koh, 2004; Dhawan, 2020). According to Pasha and Gorya's (2019) findings, most students prefer online education rather than face-to-face education. There are only $26 \%$ of students who prefer offline or face-to-face education. Students choose online education because they can take information anywhere and anytime, and they like it because many students are doing jobs with studies (Pasha \& Gorya, 2019) and choose online courses. After all, they believe it will provide a good learning experience (Farris, Haskins \& Yemen, 2003; Clinefelter \& Aslanian, 2013; Jaggars, 2014). However, a study of community college students showed that only 3\% believed that students learn more online than face-toface courses (Jaggars, 2014). In previous studies, researchers explored the factors of satisfaction of students with online learning. The satisfaction has distinguished between faculty, course, and student factors (Blackmon \& Major, 2012). Students' satisfaction with online education is an essential factor. Student satisfaction is a factor in the management of educational quality (Koper, 2015). Many researchers argued that students tend to be more satisfied in traditional classes than in online classes (Hiltz, 1994; Bali \& Liu, 2018). According to Gunawardena and Zittle (1997), the interactions between student and a teacher contribute to satisfaction.

Research has established that both quantity and quality of student interactions are significant factors and highly correlate with student satisfaction in any learning environment, either online or physical. Researchers also found that demographic and cultural background are essential factors in promoting student interaction in online learning (González-Gómez, Guardiola, Rodríguez \& Alonso, 2012).

Students are key stakeholders in any educational institution, and so their satisfaction is an important factor to maximize profitability by creating and maintaining students' trust in the learning process (Shehzadi, Nisar, Hussain, Basheer, Hameed \& Chaudhry, 2020). On the other side, students' satisfaction towards studies may be affected due to the coronavirus because educational institutions were closed, and students' studies shifted from physical to online classes. Now students are taking online classes instead of face-to-face classes.

The universities are now shifted online classes from physical classes (Shehzadi et al., 2020). In Pakistan, all universities shifted to online education for their graduate and 
post-graduate students during the lockdown. It is hard to assume that all students would have equal access to the internet and hardware to take online classes in Pakistan because of uneven access to resources. The efficacy of online classes concerning students' satisfaction with learning and their confidence in what they have academically attained during this online learning experience is a question to investigate and underscoring the importance of this study. Below, figure 1 illustrates the theoretical proposal of the current research.

\section{Figure 1}

Proposed Mediation Model for Current Research

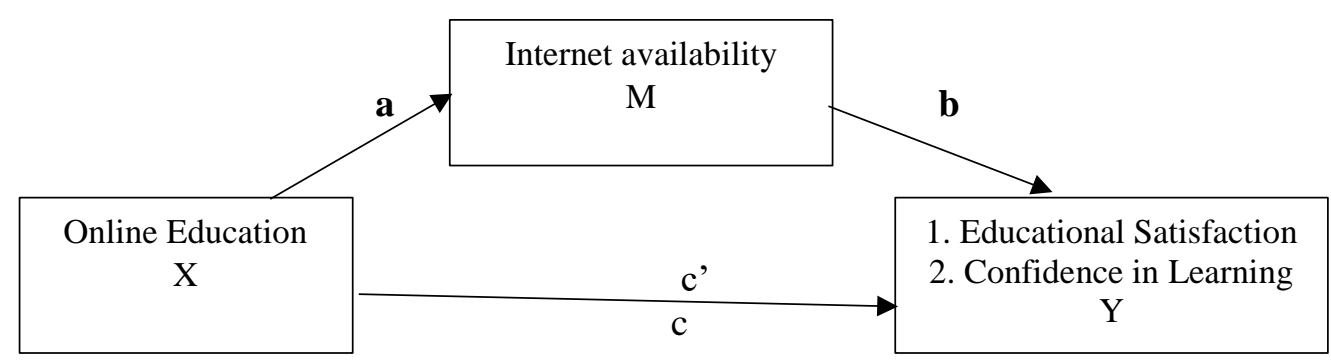

Note: This figure demonstrates the theoretical model of the research. $\mathrm{X}$ is the independent variable, $\mathrm{Y}$ is the dependent variable. $\mathrm{M}$ is mediating variable. The paths " $a$ b" is a total effect, $c$ is a direct effect, and c' is the indirect effect for all study variables.

\section{RESEARCH OBJECTIVE}

1. To find out the relationship between online education and educational satisfaction among students.

2. To explore the relationship between online education and self-confidence on materials learned.

3. To analyze the mediating role of fast and reliable internet facility between online education, educational satisfaction, and self-confidence during COVID-19.

\section{RESEARCH HYPOTHESES}

1. There is a significant relationship between online education, educational satisfaction, and self-confidence in learning amongst students during the COVID-19 lockdown.

2. There is a positive relationship between satisfaction in learning and confidence in learning. 
3. A strong internet facility for online education significantly mediates the association between educational satisfaction and self-confidence upon learning outcomes for students during COVID-19 lockdown.

\section{RESEARCH METHODOLOGY}

Quantitative research design comprising of structured questionnaire through webbased Google Forms employed to execute present research.

\section{Instruments}

Online Education is measured through a self-constructed questionnaire with seven items (e.g., I attend online lectures during lockdown) with a response pattern of (1 none of them) to (5 all of them). Other six items (e.g., the online class system is easier than traditional class) with Likert-type response patterns range from ( $1=$ strongly disagree) to (5=strongly agree).

Students' satisfaction and Self Confidence Scale (SSSCL) was used to measure the satisfaction with learning and self-confidence upon the subjects' proficiency during online classes. National League developed the scale for Nursing (2005). It contains 13 items on a five-point Likert scale response pattern ranging from 1(strongly disagree) to 5 (strongly agree). The scale was adapted to use during the lockdown period. A sample item is (The teaching methods were helpful and effective during lockdown online education) and (I know how to use online applications (zoom and other) to attend online classes).

Internet availability is measured with two items (e.g., 1. I have regular internet access for my online classes. 2. My internet connection is fast and reliable.) with Likert type response pattern ranging from 1 (agree) to 5(strongly disagree).

\section{Participants}

Data were collected from university enrolled students $(\mathrm{N}=160,30$ males \&130 females) (age range 20-40 years) from three different universities of the Punjab, Pakistan. All participants were enrolled in 16-18 years of educational (BS \& MS) programs. The respondents belong to the urban (115) and rural (44) areas of Punjab, Pakistan. Seventeen participants out of 160 were married and living with their spouses, and the rest were unmarried and living with their parents and siblings.

\section{Procedure}

Data were collected through a web-based survey. A self-explanatory form containing research objectives, research purpose, and ethical considerations was ensured in 
writing to the participants. Participation in the research was voluntary. Confidentiality is ensured in all stages of conducting and report the findings. Ethical considerations given by APA $7^{\text {th }}$ edition was followed during and after the research.

\section{RESULTS}

Table 1: Socio-demographic characteristics of the study respondents. $(N=160)$

\begin{tabular}{ccc}
\hline Variables & Frequency & $\%$ \\
\hline Do you have your personal Computer/Laptop/Cell Phone? & & \\
• Yes & 148 & 88.1 \\
- No & 12 & 7.1
\end{tabular}

How long have you been using the computer/ laptop?

- 1 Year

- 1-5 Years

- 6-10 Years

Never used the computer before pandemic

Availability of Internet/Wi-Fi at home

- Yes

- No

If yes, then what type of access do you have?

- Broadband

- Dial-up

- Mobile Data

Are you familiar with online education Apps?

- Zoom app

- Google classrooms/meet

- Other

Table 2: Pearson correlation between online education, student's satisfaction, and student's self-confidence. $(N=160)$

\begin{tabular}{lccccc}
\hline Variable & M & SD & $\mathbf{1}$ & $\mathbf{2}$ & $\mathbf{3}$ \\
\hline 1 Online & 23.90 & 6.093 & & & \\
education & 17.63 & 5.386 & $(.780)$ & $-.48^{* *}$ & $-.47^{* *}$ \\
$\begin{array}{l}\text { Students } \\
\text { satisfaction }\end{array}$ & & & & $(.889)$ & $.75^{* *}$ \\
\hline
\end{tabular}




$$
\begin{array}{lll}
3 \text { Students } & 12.73 & 3.207 \\
\text { self-confidence }
\end{array}
$$

Note;

$\mathrm{M}=$ Mean, $\mathrm{SD}=$ Standard deviation

$* * \mathrm{p}<.01$.

Table 2 showed the strongest Pearson product-moment correlation coefficient for the student's self-confidence was with the student's satisfaction $(r=.756, \mathrm{p}<.01)$. The weak negative correlation coefficient for students' satisfaction was with online education $(r=-.481, \mathrm{p}<.01)$, and students' self-confidence was with online education $(r=-.476, \mathrm{p}<.01)$. Values in diagonal parenthesis showed Cronbach's Alpha reliability for all measurements and are satisfactory.

Table 3: Mediation Analyses Between Online Education, Educational Satisfaction, Self-Confidence on Learning, and Internet Facility $(n=160)$

Online education, internet Online education, internet facility and facility and educational student's self-confidence in learning satisfaction on learning

The total effect of online education on DVs

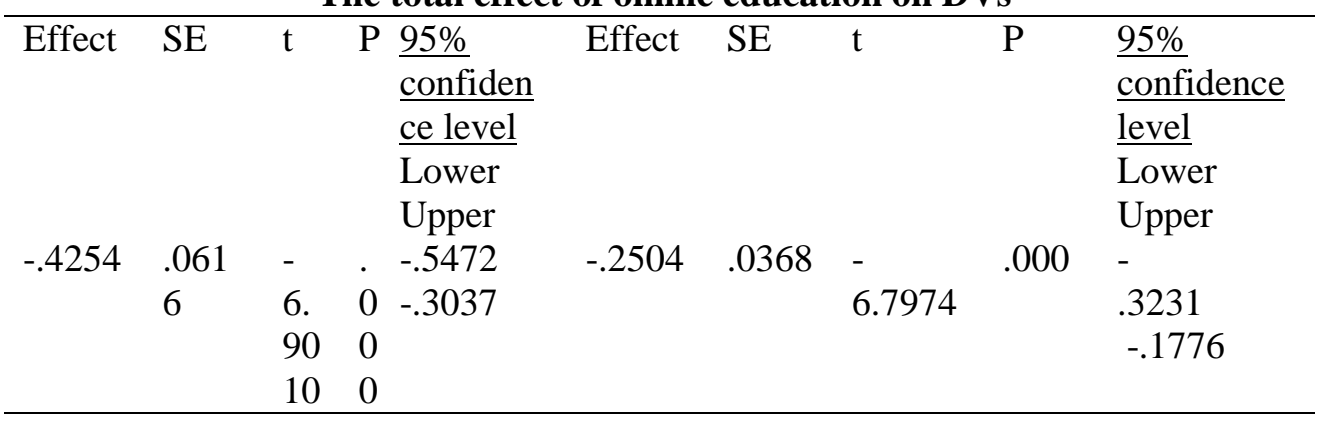

The direct effect of online education on DVs

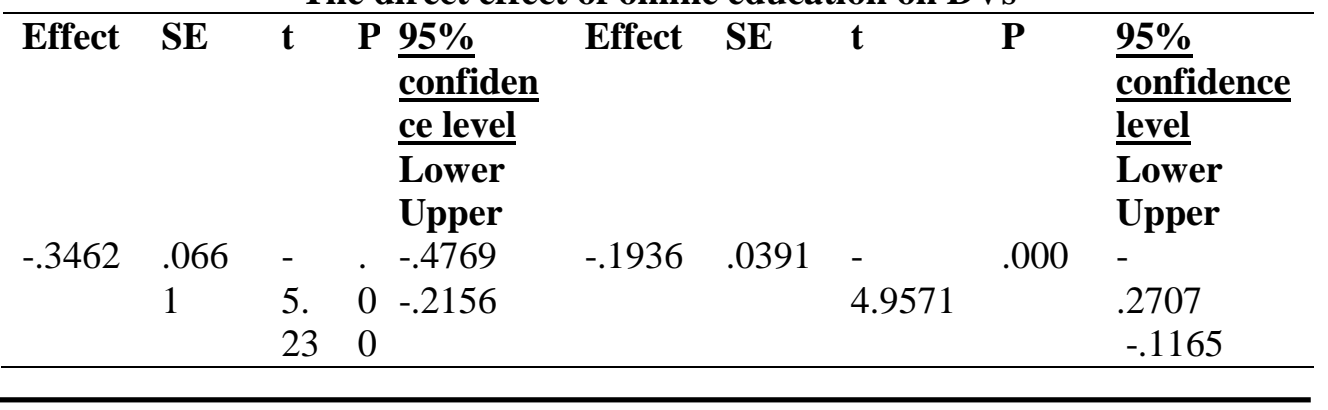




\section{Indirect effect internet facility between IV and DVs.}

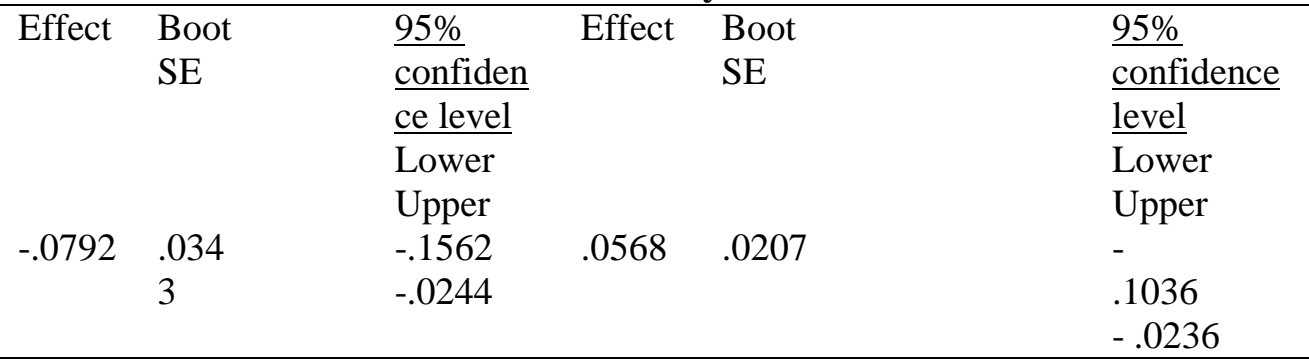

The above table showed significant indirect results between online education and students' satisfaction with learning and their confidence upon leaned materials. However, the internet facility had indirectly partially mediated the relationship between IV and DVs in the current research. The availability of the internet for online learning significantly mediate the association between educational satisfaction and self-confidence in learning for students. Internet availability played a vital mediator role.

Figure 3: Results of Mediation Analysis Between Online Education, Educational Satisfaction Mediated by Uninterrupted Internet Facility

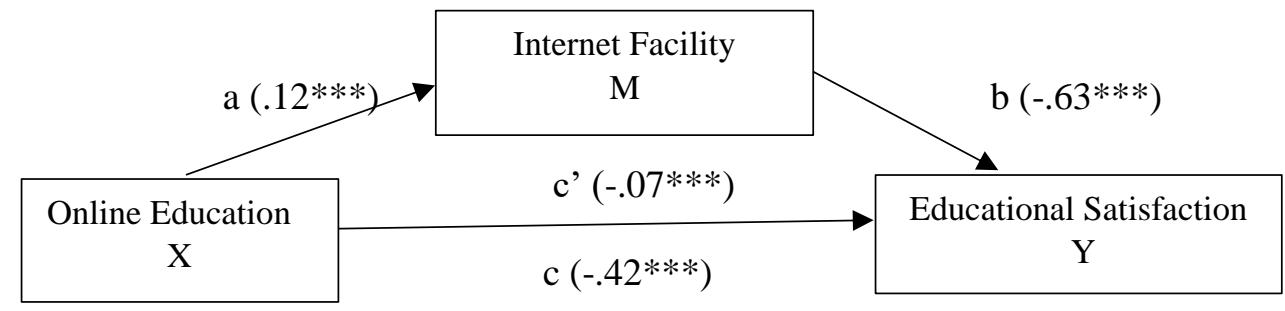

There was a significant indirect effect of internet facility on online education and student's satisfaction in learning (indirect effect: c'-c=-.35ab), (direct effect: c'=c-ab $=-.07$ ) and mediator could account for approximately $33 \%$ of the total effect during COVID-19 lockdown online education.

Figure 4: Results of Mediation Analysis Between Online Education, Confidence in Learning Mediated by Uninterrupted Internet Facility 


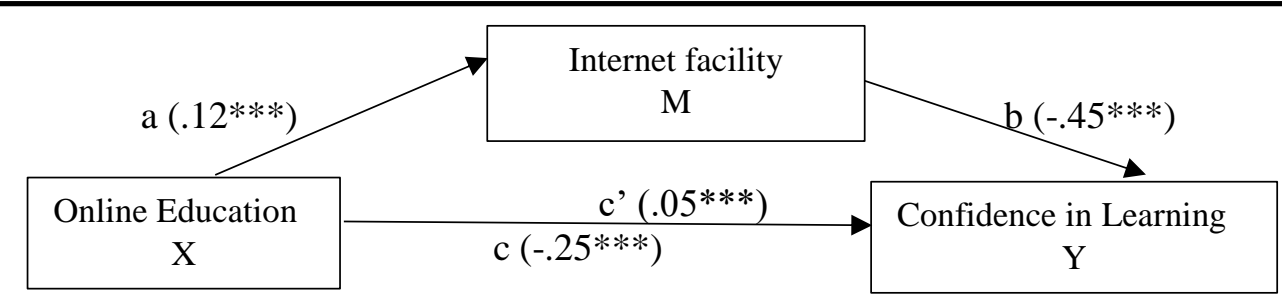

There was a significant indirect effect of internet facility on online education and students' self-confidence on online learning (indirect effect: $c^{\prime}-c=-.20 \mathrm{ab}$ ), (direct effect: $\left.c^{\prime}=\mathrm{c}-\mathrm{ab}=.05\right)$ and mediator could account for this for approximately $32 \%$ of the total effect during COVID-19 lockdown online education.

\section{DISCUSSION}

The present research investigated the impact of online education, student satisfaction, and self-confidence upon learning materials during COVID -19 in Pakistan. Findings showed a significant negative relationship between online education and students' satisfaction with online classes and their confidence in proficiency in the syllabus learned during these online classes. Little left for educational institutions to do during the COVID-19 outbreak other than going online for education to continue the academic year. However, this is a fact that in a country like Pakistan, the digital devoid is relatively high not only for the individuals owning suitable educational digital devices to the networks available for the smooth transition from in-person classes to online classes. By having no choice to start online classes immediately, the higher education institutions entered into the bandwagon of virtual education without a priori planning to run the system or foresee its impact on students learning satisfaction and confidence in the quality of materials learned. Therefore, current research focused on the issue of students' education learned through online classes, and it also focused on students' selfconfidence that they are mastering the materials learned through this online system. Though findings showed a significant positive relationship between satisfaction of studies with confidence upon learned material but both have a significant negative relationship with online education in the sample. The current sample is not satisfied with their learning, and they are also not confident in understanding the material they have learned through these online educational classes. The previous researches by Harrington and Loffredo (2010), Zvacek and Smaldino (2012), Koper (2015) indicated that most of the students prefer online classes rather than face-to-face or physical education. However, these findings are not aligned with the present research findings mainly because fast and reliable internet facilities are available in Pakistan, and there is a lack of suitable digital devices for students to own or work. The data were mainly gathered from the public sector universities of Punjab, Pakistan. Public sector 
universities usually housed students of middle to lower-middle-income strata indicating their financial ability. However, universities did not manage any hard or software facility for their students for the online educational transition. So, students and their families are left on their own to manage the internet and laptops/computers/tablets or phones to continue their education.

The availability of a solid internet facility for online education significantly mediates the association between educational satisfaction and self-confidence on learning outcomes for students during COVID-19 lockdown, and the results also revealed significant findings. The previous findings also revealed the same results. According to the findings of Kapasia et al. (2020), the use and availability of online learning resources during COVID-19 is vital for students. A study on "Conventional to online education during COVID-19 pandemic: Do develop and underdeveloped nations cope alike" by Qazi et al. (2020) also found a positive relationship between online learning and student's satisfaction towards learning during COVID-19 with a strong internet facility. However, the fast and reliable internet connection showed only $33 \%$ and $32 \%$ indirect effect for online education and student's satisfaction, and confidence in the material learned during this online system. This finding shows that students have little trust in this online system even if they have good reliable connections. Other factors as non-stop electricity supply, separate study spaces at homes during the lockdown, and sudden change in the mode of education without a priori training or orientations to students may have cast this dissatisfaction, and lowered confidence in education attained during these online classes.

The present study concludes that the online education system has not generated satisfactory results for the students, and they are not confident upon attaining capacities after their learned syllabus during online classes. Structural facilities like fast and reliable internet facilities and others can turn the table around for students' satisfaction and confidence in the material learned. It is also concluded that to deal with similar disastrous situations, and institutions should build their capacities for unforeseen circumstances.

\section{RECOMMENDATIONS}

The findings of this study should be interpreted with few margins. The web-based data were only collected from three Public Sector Universities of Pakistan. The number of respondents was limited to 160 . It is recommended to further expand this study to private higher education institutions, schools, and colleges where online education mode has opted during the COVID-19 pandemic because private institutions shifted to learning management system (LMS) swiftly than public institutions. It is 
recommended to include more participants from rural areas where structural problems are more prevalent than urban areas. This study sample belongs to urban areas where the availability of internet and electricity is better than rural areas. So, the inclusion of students from rural areas will analyze the effectiveness of online learning better. The current research recommends that fast and reliable internet connection is crucial for the proficiency of materials, so all students should be given appropriate facilities for learning in far-flung country areas. Future research should also focus on students' personality traits, student-teacher interaction, and the role of higher education institutions to continue this online education practice for unforeseen circumstances.

\section{REFERENCES}

Ali, W. (2020). Online and remote learning in higher education institutes: A necessity in light of COVID-19 pandemic. Higher Education Studies, 10(3), 16-25.

Bali, S., \& Liu, M. C. (2018, November). Students' perceptions toward online learning and face-to-face learning courses. In Journal of Physics: Conference Series (Vol. 1108, No. 1, p. 012094). IOP Publishing.

Clinefelter, D. L., \& Aslanian, C. B. (2015). Online college students 2015: Comprehensive data on demands and preferences. Louisville, KY: The Learning House-2017.

Dhawan, S. (2020). Online learning: A panacea in the time of COVID-19 crisis. Journal of Educational Technology Systems, 49(1), 5-22.

Farris, P. W., Haskins, M. E., \& Yemen, G. (2003). Executive education programs go back to school. Journal of Management Development.

González-Gómez, F., Guardiola, J., Rodríguez, Ó. M., \& Alonso, M. Á. M. (2012). Gender differences in e-learning satisfaction. Computers \& Education, 58(1), 283-290.

Gunawardena, C. N., \& Zittle, F. J. (1997). Social presence as a predictor of satisfaction within a computer-mediated conferencing environment. American journal of distance education, 11(3), 8-26.

Harrington, R., \& Loffredo, D. A. (2010). MBTI personality type and other factors that relate to preference for online versus face-to-face instruction. The Internet and Higher Education, 13(1-2), 89-95.

Hiltz, S. R. (1994). The virtual classroom: Learning without limits via computer networks. Intellect Books.

Jaggars, S. S. (2014). Choosing between online and face-to-face courses: Community college student voices. American Journal of Distance Education, 28(1), 27-38.

Jesse, G. R. (2015). Smartphone and app usage among college students: Using smartphones effectively for social and educational needs. In Proceedings of the EDSIG Conference (No. 3424).

Kapasia, N., Paul, P., Roy, A., Saha, J., Zaveri, A., Mallick, R., ... \& Chouhan, P. (2020). Impact of lockdown on learning status of undergraduate and postgraduate students during COVID-19 pandemic in West Bengal, India. Children and Youth Services 
Review, 116, 105194.

Koper, R. (2015). How do students want to learn in online distance education? Profiling student preferences. International review of research in open and distributed learning, 16(1), 307-329.

Muthuprasad, T., Aiswarya, S., Aditya, K. S., \& Jha, G. K. (2021). Students' perception and preference for online education in India during COVID-19 pandemic. Social Sciences \& Humanities Open, 3(1), 100101.

Pasha, M. A., \& Gorya, J. (2019). Student Preference and Perception towards Online Education in Hyderabad City. International Journal of Trend in Scientific Research and Development, 3(3), 656-659.

Qazi, A., Naseer, K., Qazi, J., AlSalman, H., Naseem, U., Yang, S., ... \& Gumaei, A. (2020). Conventional to online education during COVID-19 pandemic: Do develop and underdeveloped nations cope alike. Children and Youth Services Review, 119, 105582.

Rapanta, C., Botturi, L., Goodyear, P., Guàrdia, L., \& Koole, M. (2020). Online university teaching during and after the COVID-19 crisis: Refocusing teacher presence and learning activity. Postdigital Science and Education, 2(3), 923-945.

Rieley, J. B. (2020). Corona Virus and its impact on higher education. Research Gate.

Shehzadi, S., Nisar, Q. A., Hussain, M. S., Basheer, M. F., Hameed, W. U., \& Chaudhry, N. I. (2020). The role of digital learning toward students' satisfaction and university brand image at educational institutes of Pakistan: a post-effect of COVID-19. Asian Education and Development Studies.

Simonson, M., Zvacek, S. M., \& Smaldino, S. (2019). Teaching and Learning at a Distance: Foundations of Distance Education 7th Edition.

Song, L., Singleton, E. S., Hill, J. R., \& Koh, M. H. (2004). Improving online learning: Student perceptions of useful and challenging characteristics. The internet and higher education, 7(1), 59-70. UNESCO (2020). Retrieved from https://en.unesco.org/themes/educationemergencies/coronavirus-school-closures 